\title{
Monika Roszak*
}

\section{EFFECTIVE COMMUNICATION AS STRENGTHENING THE WORKING EFFICIENCY OF AN ENTERPRISE ON THE EXAMPLE OF THE DUTCH CAREYN}

\begin{abstract}
A b s t r a c t: In recent years, the interest in the issues of communication has increased significantly. The term "era of information generation" is used in relation to the current times, so the tendency to constantly improve the processes of transmission, reception and understanding is completely natural. The distinguishing feature of our times is the extremely fast pace of development of tools and means of communication. All these elements are aimed at more effective communication. Understanding the essence and importance of internal communication and their effective application will allow organizations to achieve market success and gain a competitive advantage. The article presents the internal communication system in the Dutch company Careyn and its importance for work efficiency and employee loyalty.
\end{abstract}

K e y w or d s: communication, work efficiency

JE L C o d e: M 59

\section{INTRODUCTION}

In the face of dynamically changing trends and consumer preferences in the modern economy, enterprises must constantly compete to maintain their market position and customer recognition. Growing customer requirements force the implementation of innovations necessary to gain and maintain a competitive advantage. Innovations reflecting technological progress and modernity, as well as activities in the field of sustainable development, are a factor stimulating organizational development and building a competitive advantage (Zastempowski, 2019, Wiśniewska et al., 2019, Pypłacz, 2017, p. 22). It has been emphasized many times that innovation has a significant

\footnotetext{
* Contact information: Monika Roszak, Uniwersytet Mikołaja Kopernika w Toruniu, Wydział Nauk Ekonomicznych i Zarządzania, ul. Gagarina 13a, 87-100 Toruń, e-mail: monikajoanna. roszak@gmail.com
} 
impact on the results of enterprises (Glabiszewski et al., 2018), and innovation is considered one of the most important sources of sustainable competitive advantage in an increasingly changing environment (Zastempowski, et al., 2018). Factors such as a positive image and brand awareness among customers are presented as important tools that companies use to successfully compete on the market [Wiśniewska et al., 2019].

An enterprise is a special type of social organization focused on achieving its goals. Considering that the foundation for achieving results is the organized work of many people, this means that communication between the involved participants is needed for the proper process of work flows. Its quality, precision, speed and perception ability have a significant impact on the achievement of specific goals. Many companies still underestimate the importance of communication. Communication in an organization is one of the most important problems of today's enterprises. Improper communication is the external manifestation of hidden problems of hidden disruptions in the organization.

The communication process should be as well designed as possible so that the work of a given entity is as effective and efficient as possible. Some organizations follow the development of technology, using more and more new tools to improve the communication process. Understanding the essence and importance of internal communication, learning about new tools and instruments and their effective application will allow you to effectively increase efficiency and gain a competitive advantage.

Thanks to good communication, the company can achieve success in almost every area of activity, and ignoring it - a spectacular failure.

\section{THE ESSENCE OF COMMUNICATION}

In recent years, the interest in the issues of communication has grown significantly and clearly. The era of information generation has come, and nowadays the tendency to constantly improve the processes of transmitting, receiving and understanding is completely natural. The distinguishing feature of our times is the extremely fast pace of the development of communication tools and means. All these elements are aimed at more effective communication. Before considering the methods, tools, and instruments of communication as good or bad solutions, one should consider the essence of communication. In particular, it is an information transfer process. Communication is the creation of a common social system in which two or more people participate [Bolek, 2012, pp. 133-134]. Most often, it is a dynamic process in which the sequence of behaviors is important, not only the stimulus-reaction relationships.

Communication is usually understood as the transmission of messages between the sender and the recipient. Communication itself can be described 
as a two-way process of transmitting one information to another [Griffin, 2007, p. 592]. On the other hand, effective communication is the process of sending a message (message) in such a way that the received message has the closest possible meaning to the sent message.

Each organization needs a carefully planned and actively implemented communication program that will respond to the information needs of employees and facilitate the bottom-up flow of information (employee -> manager). It is worth noting that communication is often confused with an information message, which is one-way in nature. Effective communication is two-sided, connected not only with the transfer of information, but also with its reception [Mruk, 2012, p. 167].

\section{GOALS AND COMPONENTS OF COMMUNICATION}

The most important goal of communication is to create an appropriate work environment that enables [Mruk, pp. 168-169]:

- Creation of working conditions that stimulate the growth of creativity and efficiency of employees;

- Develop a strong organizational culture based on universally accepted values and principles;

- Orientation of the management staff to the needs of employees;

- Improving communication and relations between the boss and employees as well as between colleagues;

- Increasing employee motivation by providing reliable, accurate and true information;

- Preparing employees for the upcoming changes, leading to understanding and reducing resistance to change.

Clearly defined communication goals that are understood and known to employees are compatible with the strategic goals of the organization and constitute the starting point of any effective communication program.

There are many components to the communication process. However, social communication always consists of participants - the sender and the recipient, and various, deliberately selected elements, the most common of which are: message, code, channel, information gap, disturbances, feedback and frame of reference [Zalewska-Turzyńska, 2012].

The sender (initiator of the communication process), also known as the source of the message, is a person or group of people who are aware of the need to convey certain messages in the form of a message. The sender chooses the method of contact - the way and means by which the message is conveyed to the recipient [Potocki, et al., 2003, p. 36]. In turn, the recipient is the person to whom the message is addressed and the purpose at which the message is to be reached. 
This person sees, hears, comprehends and reacts to the message addressed to him contained in the message [Zalewska-Turzyńska, 2012, p. 40].

A message is a physical form of encoding information [Schulz von Thun, et al., 2004, p. 69]. Like a message or a message, it is at the heart of the communication process. A message is a structure consisting of meaning, signs, symbols and form. Due to the purpose of the message, two types are distinguished - informative and persuasive. An informational message occurs when the sender's sole purpose is to provide information and explanations [Jowett, O'Donnell, 1989, p. 22]. Persuasive communication is about influencing others in order to achieve your own goals [Szymanek, 2004, p. 228].

Another communication component is encoding. The communication can only be through symbols, so the coding is the sender converting the information into symbols and pictures. The purpose of coding is to communicate, so the sender tries to ensure the similarity of meanings by selecting symbols, usually in the form of words or gestures, which in his opinion have the same content for the recipient. It is worth noting that the lack of similarity in meanings is one of the most common misunderstandings or the inability to communicate. Decoding is a two-step process for the receiver. The first stage is receiving the message, the second is its interpretation. It consists in recreating the meaning of the message on the basis of signs, each of which contains elements of this sense [ZalewskaTurzyńska, 2012, p. 43].

The channel is used to transmit signals from the source of information to the addressee. The communication channel is the way the sender and the recipient communicate. It is an item that mediates the flow of information, a section of informational ties between at least two members of the organization. The channel can be not only a part of the apparatus, e.g. a telephone line connecting the director with managers, the path that documents pass from one position to another, but also the vibrating air in the case of the so-called direct communication during oral transmission of information within a formal or informal organization [Zalewska-Turzyńska, 2012, p. 48].

Interference, also known as noise, is any factor that disrupts the communication process, distorts the message, causes confusion, or otherwise interferes with efficient communication. Disturbances may arise during three stages of the communication process: during encoding, in the communication channel and during decoding [Zalewska-Turzyńska, 2012, p. 54].

The next step in the communication process is the information gap. One can distinguish the information hope gap, with which the recipient agrees that it will be eliminated as a result of receiving further information in the future, and the gap of disagreement as a difference in the information content with which the recipient does not agree [Zalewska-Turzyńska, 2012, p. 56]. 
The next, very important element of the communication process is feedback. It is a reaction to communication. They can also be defined as the original transmission of the message, i.e. the recipient becomes the sender. It is the recipient's reaction to the sender's message [Zalewska-Turzyńska, 2012, p. 57].

The effectiveness of communication depends on the similarity of communication skills, attitudes, education, social experiences and culture of the participants in this process. The greater the differences within these features, the greater the likelihood of failure in communication. Inefficiency means that the meaning of the message that has been created by the recipient will differ from the meaning assumed by the sender. Effective communication is when the message is properly understood.

\section{COMMUNICATION IN THE ENTERPRISE}

Each organization should ensure the high quality of internal communication. Appropriately well and properly informed employees are more motivated, thanks to which they are more efficient and work better. In the absence of internal communication, the involvement of employees is at a lower level, and in extreme situations, there may be a lack of understanding of what work is about, what tasks should be performed and what tasks can be performed for. In the case of tasks that require individual involvement of the employee or his creativity, the lack of knowledge or understanding of the key goal may lead to making wrong decisions. Thus, having knowledge, employees have the opportunity to communicate information about the organization and its activities to their own environment. They can give good opinions to the company and the environment, which strengthens the brand of a given company [Bolek, 2012, pp. 133-134].

People responsible for internal communication in the company can use many different tools and methods of information management. The selection of these tools depends on the specificity and predisposition of a given organization, its size, financial resources, the market on which it operates and others [Olsztyńska, 2002, p. 170; Zastempowski et al., 2018].

Formal communication is the transmission of information via a path established by organizational procedures. Formal communication channels do not have to be described in the documentation specifying the operation of the company, but may be a consequence of the adopted customs of the company's organizational culture. Each enterprise has many types of formal communication channels [Olsztyńska, 2002, p. 171].

Informal communication channels are of particular importance in a company. It is often the most reliable communication channel for employees. In organizations with an organizational culture based on trust and open information, informal communication can have a very positive effect on employees and 
stimulate creativity. In enterprises with an unclear flow of information and a negative work atmosphere, informal communication often intensifies bad relations between departments, employees and their management, which reduces efficiency and increases turnover [Olsztyńska, 2002, p. 174].

Internal communication in a company is the basis for efficient organization management, and its shape and scope affect the company's long-term competitive position. The recipients of communication activities include employees who, as the basis for the functioning and development of the organization, expect reliability, transparency and timeliness of the information they receive, the possibility of openly expressing their opinions and suggestions and active participation in the decisions made. The aim of effective internal communication is to create, through formal and informal channels, working conditions that will stimulate the growth of creativity, efficiency, commitment and loyalty of employees [Olsztyńska, 2002, 178]. Thanks to this, the strength of the company's brand will be strengthened not only in the eyes of customers but also potential employees [Liczmańska, Wiśniewska 2013, Mizera, Pypłacz, 2017].

\section{COMMUNICATION AT CAREYN - CASE STUDY}

Careyn is a Dutch company with over 8,000 employees. The company has 3 locations in Utrecht. The organization has a negative image in the external environment. Has a problem with hiring interns and new employees.

It is a caring organization focused on providing a full range of care, welfare and housing services. These services are organized in a district specific way. The services offered by Careyn include:

- home care,

- home care and home care,

- youth health care,

- dietary advice,

- wellness and convenience services.

Care teams are at the heart of Careyn's services. They are small, independently operating teams of well-trained specialists who serve a permanent group of clients. Teams operate independently and use modern communication, planning and remote care tools. In residential care, orientation and coordination with the family and social network are also crucial.

Due to the large number of people employed and the variety of services provided, Careyn has many tools for information and communication. The same communication instruments are available to all employees. The company has a communication platform for employees that resembles the company's official website. It is the responsibility of each employee to check the platform daily as new information is released regularly. This practice is part of the culture of the 
organization and all employees must check the news posted on the platform. However, the problem is that employees only superficially look at the virtual page and do not read in detail as information appears. According to the employees, there is too much information posted, they are not divided into important and less important. As a result, employees cannot ultimately find the most important information intended for them.

Another instrument used to transmit information is a widely known e-mail. For Careyn, it is not possible to meet face-to-face with all of the employees because the number of employees is too high and the work system varies in terms of the form of work and working time. It turns out that e-mailing in a company is commonplace, also inscribed in the culture of the organization, but it turns out that it does not bring results. Messages are delivered via e-mail, but according to employees, there are too many messages every day. Employees do not read them, do not pay attention to them, and most of all, the vast majority do not reply to e-mails at all and do not bear any consequences for it.

Careyn uses the latest applications to aid the communication process, such as the popular WhatsApp. As you can see there are a lot of top-down information and communication tools in Careyn, but it's very inefficient. Ultimately, employees are not informed about important matters. It very often happens that information is provided in an informal way, which causes them disgust, demotivation and underestimates the company's assessment in the eyes of employees. What's more, the communication problem also appears when hiring new employees. It is worth noting that Careyn has a very wide offer of apprenticeships and internships, especially for nurses, for which the company has a very high demand. However, the introductory - training process is very negatively assessed by the trainees.

The main factor behind the negative feelings is the fact that the introductory week for interns takes place only after three weeks of the internship. Apprentices and trainees do not know what activities and tasks they should perform, which causes them a sense of discomfort and negative feelings about the internship. Despite the fact that each trainee reports to those responsible for their internship or apprenticeship, it is not enough, because they feel confused because they do not know who to turn to with the problem, how to work and what their duties are. The experience gained by interns is assessed negatively, which means that they themselves do not want to be associated with the company for the future, nor recommend Careyn to their peers.

Employees at various levels of the company feel insulted because of the lack of proper communication in the organization. They believe that there are far too many channels for sending information, information of low importance is sent, while they learn about more important information in an informal, often accidental manner. Most employees have regular meetings with their managers every 2 weeks or once a month. However, not all of them. All employees of the 
company agreed that communication could work in a better way, thanks to which they would avoid misunderstandings in their teams and between departments. There was a big conflict in the organization between the purchasing department and other departments that were not informed about the limited procurement budgets. As a result, the costs incurred were too high, and the order did not contain basic products.

\section{SUMMARY}

The article deals with the problem of the impact of proper communication on work efficiency in an enterprise. It is worth noting that the potential of the current Careyn employees is huge. It was the employees who suggested changes that could be introduced to improve the communication process in the enterprise. For example, the aforementioned platform for employees, in their opinion, should be visually changed, detailing the most important information that should be paid attention to in the first place. Employees appreciate the benefits that the organization offers them, such as Christmas vouchers or help when employees have health problems. However, a group of nurses had a different opinion. They felt very underestimated by the company, they often changed employment when there was an opportunity to work in another company, especially in a hospital.

Careyn is an organization with great potential, it is one of the largest enterprises in Utrecht, the Netherlands, which has been trusted by customers - the company's patients for years. However, as you can see, due to neglect, an inadequately managed communication process, the company loses its value in the eyes of employees and potential employees, and loses its effectiveness and efficiency through demotivation in the activities of its personnel. Consequently, it may translate into a negative image in the eyes of the company's environment.

\section{BIBLIOGRAPHY}

Bolek J., Efektywne wykorzystanie klasycznych narzędzi komunikacji wewnętrznej przez przedsiębiorstwo, [w:] W. Harasim, ,Zarzadzanie kapitatem intelektualnym w organizacji inteligentnej”, Wyższa Szkoła Promocji, Warszawa 2012.

Glabiszewski W., Liczmańska-Kopcewicz K., Zastempowski M., Znaczenie zdolności asymilacyjnych $w$ budowaniu innowacyjności technologicznej przedsiębiorstw finansowych, Przedsiębiorczość i Zarządzanie, 19(3), 2018, 169-181.

Griffin R. W., Podstawy zarządzania organizacjami, Wydawnictwo Naukowe PWN, Warszawa 2007.

Jowett G., O’Donnell V., Propaganda nad Persuasion, Stage, Beverly Hills 1989.

Lesly's Hanbook, Public Rekations nad Communications, red. P. Lesly, wyd.4, American Managemnt, New York 1993.

Liczmańska-Kopcewicz K., Mizera K., Pypłacz P., (2019), Corporate Social Responsibilitry and Sustainable Development for Creating Value for FMCG Sector Enterprises, „Sustainability”, 11(20), 5808. 
Liczmańska K., Wiśniewska A., Znaczenie marki dla konsumenta na przykładzie województwa kujawsko-pomorskiego, AUNC Zarządzanie, 40, 2013, 71-83.

Mizera K., Pypłacz P., CSR w obszarze pracowniczym, Marketing i Rynek, 11, 2017, 371-381.

Mruk H., Komunikowanie się w biznesie, Wydawnictwo Akademii Ekonomicznej w Poznaniu, Poznań 2002.

Olsztyńska A., Komunikacja wewnętrzna w przedsiębiorstwie, [w:] H. Mruk, „Komunikowanie się w biznesie”, Wydawnictwo Akademii Ekonomicznej w Poznaniu, Poznań 2002.

Potocki A., Winkler R., Żbikowska A., Techniki komunikacji w organizacjach gospodarczych, Wyd. Difin, Warszawa 2003.

Pypłacz P. (2017) 'Innowacje organizacyjne w małych i średnich przedsiębiorstwach', Management Forum, 5(4), 21-26.

Schulz von Thun F., Ruppel J., Stratmann R., Sztuka zarzadzania. Psychologia komunikacji dla szefów i liderów, Wyd. WAM, Kraków 2004.

Szymanek K., Sztuka argumentacji. Słownik terminologiczny, Wyd. Nauk PWN, Warszawa 2004.

Wiśniewska A., The mission \& vision statements in the consumers 'strategies, AUNC Zarządzanie, 3, 2018, 111-118.

Wiśniewska A., Liczmańska-Kopcewicz K., Jagielski M., The image transfer in franchise system - the conceptual approach, Marketing i Rynek, 5, 2019, 13-20.

Zalewska-Turzyńska M, Komunikowanie się w organizacji - studium prakseologiczne, Wydawnictwo Uniwersytetu Łódzkiego, Łódź 2012.

Zastempowski, M., Innowacyjność matego przedsiębiorstwa, Toruń, Wydawnictwo Naukowe Uniwersytetu Mikołaja Kopernika, 2019.

Zastempowski M., Glabiszewski W., Liczmańska-Kopcewicz K., Makrootoczenie polskich MŚP w kontekśsie ich innowacyjności, Organizacja i Kierowanie, 2(181), 2018, 119-134.

https://sjp.pwn.pl/sjp/komunikat;2472919.html

\section{SKUTECZNA KOMUNIKACJA JAKO WZMOCNIENIE WYDAJNOŚCI PRACY PRZEDSIĘBIORSTWA NA PRZYKŁADZIE HOLENDERSKIEGO CAREYN}

Streszczenie: W ostatnich latach zainteresowanie problematyką komunikowania się zdecydowanie i wyraźnie wzrosło. Mówi się o epoce pokolenia informacyjnego, zatem tendencja do ciągłego usprawniania procesów przekazywania, odbioru, rozumienia, jest zupełnie naturalna. Wyróżnikiem obecnych czasów jest niezwykle szybkie tempo narzędzi i środków komunikowania się. Wszystkie te elementy mają na celu efektywniejsze porozumiewanie się. Zrozumienie istoty i znaczenia komunikacji wewnętrznej oraz ich skuteczne zastosowanie pozwoli na osiąganie sukcesów rynkowych i uzyskanie przewagi konkurencyjnej. W artykule zaprezentowano system komunikacji wewnętrznej $\mathrm{w}$ holenderskim przedsiębiorstwie Careyn oraz jego znaczenie dla efektywności pracy oraz lojalności pracowników.

Słowa kluczowe: komunikacja, komunikowanie się, wydajność pracy 
